\title{
DEATH BY NUMBERS: WHY EVOLVING STANDARDS COMPEL EXTENDING ROPER'S CATEGORICAL BAN AGAINST EXECUTING JUVENILES FROM 18 TO 21
}

\author{
John H. Blume* \\ Hannah L. Freedman ${ }^{* *}$ \\ Lindsey S. Vann ${ }^{* * *}$ \\ Amelia Courtney Hritz ${ }^{* * * *}$
}

\section{CONTENTS}

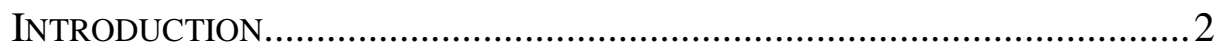

I. JUVENILE SENTENCING FROM ROPER TO MONTGOMERY ................. 3

A. THE SUPREME COURT'S JURISPRUDENCE ON EVOLVING STANDARDS OF DECENCY .....................................

B. EVOlVing STANDARDS OF DECENCY AND JUVENILE

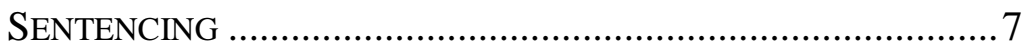

II. SOCIAL AND SCIENTIFIC CHANGES SINCE ROPER .........................10

A. Novel Research in Neuroscience and Brain

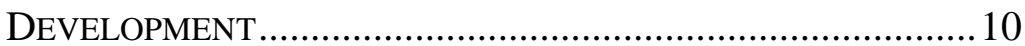

B. SOCIETY'S TREATMENT OF PEOPLE UNDER 21.......................15

III. Death SENTENCES ANd Executions of Youthful

OFFENDERS SINCE ROPER ……………………………............. 17

A. Methodology ……………………………………….......19

B. DEATH SENTENCING SinCE ROPER.........................................20

C. EXECUtions of Youthful OfFENDERS Since

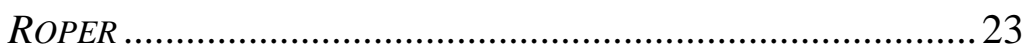

IV. RACIAL Disparity IN YOUTHFUl OfFENDER

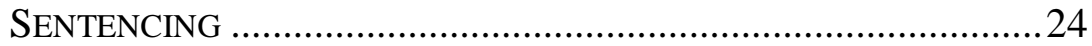

A. HISTORICAL EVIDENCE OF RACIAL DISPARITY IN THE SENTENCING OF Young PEOPLE............................................24

B. Racial Disparity in Youthful OfFENDER DEATH SENTENCES AND EXECUTIONS SINCE ROPER..........................27

CONCLUSION ........................................................................................

* Samuel F. Leibowitz Professor of Trial Techniques, Cornell Law School, and Director, Cornell Death Penalty Project.

${ }^{* *}$ Fellowship Attorney, Justice 360; J.D., Cornell Law School, 2016.

**** Executive Director, Justice 360, Columbia, South Carolina.

${ }^{* * * *}$ Robert B. Kent Public Interest Fellow, Cornell Law School and Justice 360; J.D., Cornell Law School, 2017, Ph.D., Cornell University, 2018.

The authors would like to thank Seantyel A. Hardy, Kate Bridal Lebsock, and Carrie Montgomery for their research and data collection assistance. They would also like to thank Daniel Ottaunick for his editorial help 
Nearly fifteen years ago, the Supreme Court held in Roper v. Simmons that the Eighth Amendment prohibits the execution of people who were under 18 at the time of their offenses. The Court justified the line it drew based on legislative enactments, jury verdicts, and neuroscience. In the intervening years, however, much has changed in juvenile sentencing jurisprudence, the legal treatment of young people, and neuroscience. These changes beg the question: Why 18? Is the bright-line rule that the Court announced in Roper still constitutionally valid or do the changes since 2005 now point to a new cutoff at 21?

To answer those questions, this Article considers post-Roper developments in the relevant domains to make the case that the 18-year-old constitutional line should be extended to age 21. It does so by applying the Supreme Court's evolving-standards-of-decency methodology. Specifically, the Article examines all death sentences and executions imposed in the United States post-Roper and looks at the current state of neuroscientific research that the Court found compelling when it decided Roper.

Two predominant trends emerge. First, there is a national consensus against executing people under 21. This consensus comports with what new developments in neuroscience have made clear: people under 21 have brains that look and behave like the brains of younger teenagers, not like adult brains. Second, young people of color are disproportionately sentenced to die-even more so than adult capital defendants. The role of race is amplified when the victim is white. These trends confirm that the logic that compelled the Court to ban executions of people under 18 extends to people under 21.

\section{INTRODUCTION}

In April of 1997, 18 year old Justin Chaz Fuller and three other people-25-year-old Elaine Hays, 20-year-old Samhermundre Wideman, and 19-year-old Brent Chandler-broke into a college student's apartment in Tyler, Texas, robbed him, and drove him in his car to a park where he was shot and killed. ${ }^{1}$ Over the course of the next few days, someone brought a group of students from the local high school to see the victim's body and, unsurprisingly, one of them contacted law enforcement. ${ }^{2}$ When the police arrested Justin a few days after the killing, he waived his Miranda rights and gave an uncounseled confession in which he admitted

1 See Texas Execution Information Center, Execution Report: Justin Fuller, http://www.txexecutions.org/reports/374-Justin-Fuller.htm (last visited Jan. 26, 2019); Death Penalty Information Center, Those Executed: Under 21 at Time of Crime, https://deathpenaltyinfo.org/ThoseExecuted_Under21AtTimeofCrime (last visited Jan. 26, 2019). At the time of the crime for which he was executed, Justin had no criminal record. Fuller v. State, 2000 WL 3432767, at *1 (Ct. Crim. App. Texas Dec. 20, 2000). He was applying to college that spring. Fuller, 2000 WL 3432767, Br. for Appellant, No. 73,106, 1999 WL 33748921, at *32 (Aug. 19, 1999).

2 Texas Execution Information Center, Execution Report: Justin Fuller, http://www.txexecutions.org/reports/374-Justin-Fuller.htm (last visited Jan. 26, 2019) 
being present for the murder but denied being the triggerman. ${ }^{3}$ No forensic evidence indicated which of the four codefendants pulled the trigger.

Justin, who was black, went to trial first; ${ }^{4}$ he was convicted of murder and sentenced to death by a jury of eleven whites and one AfricanAmerican. ${ }^{5}$ The trial judge refused to admit evidence that co-defendant Samhermundre (who Justin maintained was the shooter) had a lengthy criminal record and told his girlfriend that it "felt good to shoot somebody." 6 The verdict sheet did not require the jury to determine whether Justin was the triggerman because under Texas law, his participation in the robbery and kidnapping was sufficient for the jury to return a death sentence. ${ }^{7}$ After all of his appeals were rejected by the state and federal courts, Justin was executed by lethal injection in 2006. He was 27 years old.

The year before Justin's execution, the Supreme Court of the United States created a categorical ban prohibiting the execution of people who were under the age of 18 when they committed a capital offense. ${ }^{8}$ In announcing this categorical ban, the Court acknowledged that "[d]rawing the line at 18 years of age is subject, of course, to the objections always raised against categorical rules" and "[t]he qualities that distinguish juveniles from adults do not disappear when an individual turns 18."9 Nevertheless, in recognition that "a line must be drawn," the Roper Court embraced a bright-line cutoff at age $18 .{ }^{10}$ Justin fell on the wrong side of that line by a few months.

In the fourteen years since Roper, the scientific, legal, and societal

${ }^{3}$ Fuller v. Dretke, 161 F. App’x 413, 415 (5th Cir. 2006); Fuller, 2000 WL 3432767, Br. for Appellant, No. 73,106, 1999 WL 33748921, at *xxvii.

${ }^{4}$ Fuller, 2000 WL 3432767, Br. for Appellant, No. 73,106, 1999 WL 33748921, at *xxvii. Brent Chandler took a plea for 25 years and testified against Justin; Samhermundre Wideman went to trial separately and received a life sentence; Elaine Hays also received a life sentence. See Fuller, 2000 WL 35432767, at*1 n.4; Texas Tribune, Texas Prison Inmates: Elaine Kay Hays, https://www.texastribune.org/library/data/texasprisons/inmates/elaine-kay-hays/1118180/; Texas Tribune, Texas Prison Inmates: Samhermundre Raemune Wideman, https://www.texastribune.org/library/data/texasprisons/inmates/samhermundre-raemune-wideman/1198507/. Brent Chandler was released early and is not currently serving a prison sentence.

${ }^{5}$ Fuller, 2000 WL 3432767, Br. for Appellant, No. 73,106, 1999 WL 33748921, at *102-06 (Aug. 19, 1999).

${ }^{6}$ Fuller v. Dretke, 161 F. App’x at 415-16, 422.

7 Texas v. Fuller, No. 241-80814-97, 1998 WL 35255778 (Texas Dist. Ct. March 4, 1998), jury verdict form.

${ }^{8}$ Roper v. Simmons, 543 U.S. 551 (2005).

${ }^{9}$ Id. at 574 .

${ }^{10}$ The Court selected 18 because, it explained, "[t]he age of 18 is the point where society draws the line for many purposes between childhood and adulthood," and because the then-available neuroscience indicated that the brains of 18-year-olds were underdeveloped relative to those of older people. $I d$. at 573-74. 
understanding of youth's significance has fundamentally changed. Neuroscience has revealed a more nuanced understanding of the physiological markers of youth, how those markers affect behavior, and ways in which young people's brains continue developing into their mid20s. At the same time, society's understanding of what it means to be a young person has evolved, and capital sentencing practices reflect that evolution by limiting the death penalty's use against youths under the age of 21. These changes beg the question: Why 18? Are the underlying principles about youth that gave rise to Roper's 18-year cutoff still socially and scientifically valid? Although some litigants have argued in favor of extending Roper's categorical ban beyond the age of 18, there is a dearth of scholarly research addressing social and scientific changes since Roper. ${ }^{11}$

This article seeks to answer these questions using the Supreme Court's evolving standards Eighth Amendment methodology. Based on our analysis of post-Roper death sentences and executions, viewed against the new, more nuanced understanding of juvenile brain development, we conclude a cutoff of 18 years old is no longer supportable; instead, the cutoff should be raised to 21. In Part I, we review the Supreme Court's jurisprudence on evolving standards of decency and how its treatment of youth has changed since Roper. In Part II, we review the work of neuroscientists focused on brain development in young people and explore how novel technology since Roper has eroded the scientific basis for Roper's 18-year cutoff. ${ }^{12}$ We also describe ways in which society treats people under 21 like children, not adults. In Part IV, we discuss our methodology and present our analysis of death-sentencing and executions of youthful offenders since Roper, including a review of racial disparities revealed by that data. We conclude by discussing the implications of our data and analysis.

\section{JUVENILE SENTENCING FROM ROPER TO MONTGOMERY}

\section{A. The Supreme Court's Jurisprudence on Evolving Standards of Decency}

In Roper $v$. Simmons, the Court held the execution of a juvenile offender-one under the age of 18 at the time of the offense-violates the

\footnotetext{
${ }^{11}$ For example, in 2017 a Kentucky trial court agreed that Roper should be extended to cover offenders under the age of 21 and barred the death penalty for a 20 year old individual charged with a capital crime. Commonwealth v. Brehold, No. 14-CR-161, slip op. (Ky. Cir. Ct. Aug. 1, 2017).

12 The authors of this article are not neuroscientists or neuropsychologists. The aim of Part II is to provide an overview of some legally relevant developments in the field of brain science since Roper, not to offer any novel interpretations of the relevant science.
} 
Eighth Amendment's prohibition on cruel and unusual punishment. ${ }^{13}$ The Eighth Amendment proscribes "all excessive punishments, as well as cruel and unusual punishments that may or may not be excessive." ${ }^{14}$ This proscription "flows from the basic precept of justice that punishment for a crime should be graduated and proportioned to the offense." 15 Punishment is "cruel and unusual" if there is either a general societal consensus against its imposition or if its imposition affronts "the basic concept of human dignity at the core of the Amendment" because it is disproportionate to the offender's moral culpability. ${ }^{16}$ Each of these Eighth Amendment principles "must draw its meaning from the evolving standards of decency that mark the progress of a maturing society."17

"[T]he standard of extreme cruelty ... itself remains the same, but its applicability must change as the basic mores of society change."18 "[E]volving standards of decency," in turn, are measured by reference to whether a "national consensus" supports a categorical prohibition on a given punishment. ${ }^{19}$ To ascertain whether or not such a consensus exists, the Court considers “objective indicia of society's standards, as expressed in legislative enactments and state practice with respect to executions."20 Although legislative enactments constitute the "clearest and most reliable objective evidence of contemporary values,"21 “actual sentencing practices are [also] an important part of the Court's inquiry into consensus." ${ }^{22}$ To identify a national consensus, the Court holds "it is not so much the number" of states that technically authorize a sentence that is significant, "but the consistency and the direction of the change" relative to that

13543 U.S. at 571-73. The Roper Court defined "juveniles" as offenders under the age of 18 at the time of the offense. However, the Court adopted an 18-year bright line at least in part because the respondent, Christopher Simmons, advocated for such a cutoff, based on the scientific and social information available in 2005, as well as the fact that Christopher Simmons was himself 17 at the time of his offense. Roper v. Simmons, 2004 WL 1947812, Resp. Br. at 28.

${ }^{14}$ Atkins v. Virginia, 536 U.S. 304, 311 n.7 (2002) (citing Trop v. Dulles, 356 U.S. 861 101 (1958) (plurality opinion)).

${ }^{15}$ Kennedy v. Louisiana, 554 U.S. 407, 419 (2008) (quotation and alteration omitted).

${ }^{16}$ Gregg v. Georgia, 428 U.S. 153, 182 (1976) (opinion of Stewart, J.).

17 Trop, 356 U.S. at 101.

${ }^{18}$ Kennedy, 554 U.S. at 419 (quoting Furman v. Georgia, 408 U.S. 238, 382 (1972) (Burger, C.J., dissenting)).

${ }^{19}$ See Atkins, 536 U.S. at 312-14.

${ }^{20}$ Roper, 543 U.S. at 563; see also Coker v. Georgia, 584 U.S. 584, 593-97 (1977) (plurality opinion) (considering the sentencing behavior of juries as well as legislative decision-making); Enmund v. Florida, 458 U.S. 782, 788 (1982) (looking to "historical development of the punishment at issue, legislative judgments, international opinion, and the sentencing decisions juries have made”).

${ }^{21}$ Atkins, 536 U.S. at 312 (quoting Penry v. Lynaugh, 492 U.S. 302, 331 (1989)).

${ }^{22}$ Graham v. Florida, 560 U.S. 48, 62 (2010). 
sentence. $^{23}$

When the Court identifies the existence of a national consensus, it then exercises its independent judgment to decide whether there is reason to disagree with (or accept) the national consensus. ${ }^{24}$ "The penological justifications for the sentencing practice are ... relevant to [this] analysis" because although "[c]riminal punishment can have different goals, and choosing among them is within a legislature's discretion, ... [a] sentence lacking any legitimate penological justification is by its nature disproportionate to the offense.”" ${ }^{25}$ The Court has identified four valid penological justifications for punishment: retribution, deterrence, incapacitation, rehabilitation. ${ }^{26}$ In the capital context, however, only two of those justifications are relevant- "retribution and deterrence of capital crimes of prospective offenders." ${ }^{27}$ If a capital sentence does not serve those objectives with respect to a class of offenders, thus, the sentence is disproportionate. Additionally, when the Court evaluates the justifications for a capital sentence, it applies a special standard: "[b]ecause the death penalty is the most severe punishment, the Eighth Amendment applies to it with special force." 28 Thus, a sentence of death violates the Eighth Amendment if the sentencer's discretion is insufficiently channeled. ${ }^{29}$ Over the last two decades, the Supreme Court has applied these principles to gradually restrict the classes of defendants who may be exposed to the possibility of capital punishment. ${ }^{30}$

${ }^{23}$ Atkins, 536 U.S. at 315.

${ }^{24}$ Id. at 321; MARC J. TASSÉ \& John H. Blume, InTEllectual Disability AND the DEATH PENALTY 41 (2018).

${ }^{25}$ Graham, 560 U.S. at 71.

${ }^{26}$ Id. (citing Ewing v. California, 538 U.S. 11, 25 (2003) (plurality opinion)).

${ }^{27} \mathrm{Gregg}, 428$ U.S. at 184 . Incapacitation is equally well served by a sentence of life without the possibility of parole, and rehabilitation is not a possibility for a dead person.

${ }^{28}$ Roper, 543 U.S. at 568.

${ }^{29}$ Zant v. Stephens, 462 U.S. 862 (1983).

${ }^{30}$ For example, in Coker v. Georgia, the Court held that the death penalty is categorically "an excessive penalty for the rapist who, as such, does not take human life" and is therefore less culpable than a murderer. 433 U.S. at 593-97. Likewise, in Enmund v. Florida, the Court held that the death penalty is a categorically disproportionate punishment for individuals convicted of murder who did not directly participate in a killing because of their diminished culpability relative to that of the direct participants. 458 U.S. at 797-99; but see Tison v. Arizona, 481 U.S. 137, 152 (1987) (finding that the death penalty may be imposed for felony murder when the defendant's participation is major and the mental state is one of reckless indifference to the value of human life).

More recently, the Court held in Atkins v. Virginia that a sentence of death is a categorically disproportionate punishment for offenders with intellectual disability because of their diminished culpability. 536 U.S. at 318, 320. In Atkins, the Court identified specific deficiencies shared by people with intellectual disability that reduce their culpability as a class, regardless of their crimes: "they have diminished capacities to understand and 


\section{B. Evolving Standards of Decency and Juvenile Sentencing}

In 2005, the Roper Court overruled two prior decisions ${ }^{31}$ and held the execution of a juvenile offender violates the Eighth Amendment because the severity of the punishment is categorically disproportionate to the offender's diminished personal responsibility for the crime. ${ }^{32}$ As it had done in prior evolving-standards cases, the Court began by identifying a national consensus by referencing "objective indicia": "the rejection of the juvenile death penalty in the majority of States; the infrequency of its use even where it remains on the books; and the consistency in the trend toward abolition of the practice." 33

Consistent with its settled methodology, the Court then set about determining whether the national consensus comported with its own judgment about the proportionality of the death penalty for juveniles. The Court began by describing class-wide traits shared by people under the age of 18 that diminish their culpability, regardless of the nature of their offense: (1) they have a "lack of maturity and an underdeveloped sense of responsibility" that "often result in impetuous and ill-considered actions and decisions"; (2) they are "more vulnerable or susceptible to negative influences and outside pressures, including peer pressure"; and (3) their characters are "not as well formed" and their personalities "more transitory, less fixed" than those of adults. ${ }^{34}$ These traits of the young, the Court explained, "render suspect any conclusion that a juvenile falls among the worst offenders," and once their diminished culpability is recognized, "it is evident that the penological justifications for the death penalty apply to them with lesser force than to adults." ${ }^{35}$ As for the first penological

process information, to communicate, to abstract from mistakes and learn from experience, to engage in logical reasoning, to control impulses, and to understand the reactions of others," "they often act on impulse rather than pursuant to a premeditated plan," and "in group settings they are followers rather than leaders.” Id. at 318.

31 See Stanford v. Kentucky, 492 U.S. 361 (1989) (concluding the Eighth and Fourteenth Amendments did not proscribe the execution of offenders over 15 but under 18 because 22 of 37 death penalty States permitted that penalty for 16-year-old offenders, and 25 permitted it for 17-year-olds, thereby indicating there was no national consensus); Thompson v. Oklahoma, 487 U.S. 815, 818-838 (1988) (plurality opinion finding that national standards of decency did not permit the execution of any offender under age 16 at the time of the crime).

32543 U.S. at $571-73$.

${ }^{33} \mathrm{Id}$. at 567. At the time that Roper was decided, eighteen states had expressly banned the execution of offenders under eighteen, and twelve states had abolished the death penalty entirely. Id. at 564-65. The Court counted those states as a group and concluded that "30 States prohibit the juvenile death penalty." Id. at 564.

${ }^{34} \mathrm{Id}$. at $569-70$.

${ }^{35} \mathrm{Id}$. at $570-71$. 
objective of the death penalty, retribution, "the case for [it] is not as strong with a minor as with an adult" because "[r]etribution is not proportional if the law's most severe penalty is imposed on one whose culpability or blameworthiness is diminished, to a substantial degree, by reason of youth and immaturity." 36 And as for deterrence, "it is unclear whether the death penalty has a significant or even measurable deterrent effect on juveniles" because " "[t]he likelihood that the teenage offender has made the kind of cost-benefit analysis that attaches any weight to the possibility of execution is so remote as to be virtually nonexistent.",37

After Roper, the Court began to apply the "children are constitutionally different from adults” rationale to noncapital sentencing. First, in Graham v. Florida, the Court barred sentences of life without parole for nonhomicide offenders who were under 18 at the time of their crimes. ${ }^{38}$ Two years later, the Court held in Miller v. Alabama that the Eighth Amendment prohibits the mandatory imposition of life without the possibility of parole for juvenile offenders. ${ }^{39}$ Finally, in 2016, the Court held that Miller was a substantive rule of criminal procedure and that it therefore was entitled to retroactive application to cases that were final on direct review at the time Miller was decided. ${ }^{40}$

As it did in Roper, the Court in Graham and Miller found national consensuses against the punishments based on objective measures. The Court's focus, however, shifted from "widespread legislative authorization" to the infrequency with which states carried out the punishments at issue. ${ }^{41}$ For example, in Graham, the Court's analysis depended on the fact that

${ }^{36} \mathrm{Id}$. at 571 .

${ }^{37} \mathrm{Id}$. at 571-72 (quoting Thompson, 487 U.S. at 837).

38560 U.S. at $71-72$.

39567 U.S. 460, 480 (2012).

${ }^{40}$ Montgomery v. Louisiana, 136 S. Ct. 718 (2016).

${ }^{41}$ Miller, 567 U.S. at 482-83; Graham, 560 U.S. at 62-63; Robert J. Smith et al., The Way the Court Gauges Consensus (and How to Do It Better), 35 CARDOzO L. REV. 2397, 2451 (2014). In Graham, the Court began its analysis by noting that six jurisdictions at that time barred life sentences for people under eighteen and seven jurisdictions that permitted life without parole sentences for people under eighteen, but only for homicide crimes. Graham, 560 U.S. at 62. The Court stated that the State's argument-that because only thirteen states explicitly banned the sentencing practice at issue, there was no national consensus-was “incomplete and unavailing” because "[a]ctual sentencing practices are an important part” of the inquiry. Id. Similarly, the Miller Court rejected the States' argument that because a majority of jurisdictions statutorily authorized life-without-parole-sentences for juveniles, there could be no consensus against it. Miller, 567 U.S. at 482-83. In Miller, the Court concluded that the "the States' argument on this score [was] weaker than the one we rejected in Graham" because the outcome was not based solely on consensus, but instead "flow[ed] straightforwardly from our precedents: specifically, the principle of Roper, Graham, and our individualized sentencing cases that youth matters for purposes of meting out the law's most serious punishments.” Id. at 482-83. 
only 123 individuals were serving life without parole sentences for nonhomicide offenses they committed when they were under the age of eighteen. ${ }^{42}$ The Court contextualized those numbers by comparing them to the much larger category of teenaged offenders who were arrested for nonhomicide crimes that might have exposed them life without parole. ${ }^{43}$ The Court concluded that, given the small number of juvenile nonhomicide offenders serving life without parole, "[t]he sentencing practice now under consideration is exceedingly rare. And 'it is fair to say that a national consensus has developed against it."’44

Similarly, in Miller the practice at issue-sentencing juvenile homicide offenders to mandatory life without parole-was not only authorized but required in twenty-nine states. ${ }^{45}$ The Court found a national consensus against the practice, despite the penalty's widespread availability, and reasoned the twenty-nine states that authorized the sentences did so by route of "inadvertent legislative outcomes." 46

The Court in Roper, Graham, Miller, and Montgomery also cited developments in neuroscience and social science that confirmed a commonsense observation: young people's brains are different from adult brains in ways that make young people less morally responsible for their actions. ${ }^{47}$ Given juveniles' diminished moral culpability, the punishments at issue lacked "any legitimate penological justification." 48 The rationale that underpins the court's judgment in all of these cases is that youth is uniquely mitigating. " '[J]ust as the chronological age of a minor is itself a relevant mitigating factor of great weight, so must the background and development of a youthful defendant be duly considered' in assessing his culpability." 49 Moreover, in reaching the conclusion that adolescents under eighteen cannot be executed, the Roper Court acknowledged that "[t]he qualities that distinguish juveniles from adults do not disappear when an individual turns 18." ${ }^{\circ}$ To the contrary, the Court concluded that "a line must be drawn" and,

${ }^{42} I d$. at $63-64$.

${ }^{43} \mathrm{Id}$. at $65-66$.

${ }^{44}$ Id. at 67 (quoting Atkins, 536 U.S. at 316).

${ }^{45}$ The legislative enactments providing for mandatory juvenile life without parole that were at issue in Miller were poor indicators "that many States actually 'intended to subject such offenders' to those sentences" because the mandatory nature of the sentencing schemes precluded juries and judges from providing evidence of actual sentencing practices. Id. at 485-87 (quoting Graham, 560 U.S. at 67).

${ }^{46} \mathrm{Id}$. at 487.

${ }^{47}$ See Miller, 567 U.S. at 471-72 (“Our decisions [in Roper and Graham] rested not only on common sense — on what 'any parent knows' — but on science and social science as well.”).

${ }^{48}$ Graham, 560 U.S. at 71-72 (2010).

${ }^{49}$ Miller, 567 U.S. at 476 (quoting Eddings v. Oklahoma, 455 U.S. 104, 116 (1982)).

${ }^{50}$ Roper, 543 U.S. at 574. 
based on the scientific and social information that was available in 2005 when the Court was considering Roper, it concluded that 18 was an appropriate place to draw the line. ${ }^{51}$

Although it is true, as the Roper Court acknowledged, that any brightline rule is susceptible to criticism, ${ }^{52}$ it is also true that when the Court has drawn bright lines that are later shown to lack social and scientific support, it has redrawn the lines. In Roper, the Court revisited a prior decisionThompson-because the scientific and societal bases upon which Thompson stood could no longer support an age cutoff of $16 .{ }^{53}$

\section{SOCIAL AND SCIENTIFIC CHANGES SINCE ROPER}

\section{A. Novel Research in Neuroscience and Brain Development}

In the years since Roper, developments in neuroscience have made clear that the line the Court chose in Roper-18 years-is too low. ${ }^{54}$

${ }^{51} I d$.

52 Roper, 543 U.S. at 574. The Court noted that "[t]he qualities that distinguish juveniles from adults do not disappear when an individual turns 18," but “some under 18 have already attained a level of maturity some adults will never reach." Some of the criticisms against a bright-line rule based on age are laid out in Justice O'Connor's dissent in Roper: a bright-line rule "is premised on differences in the aggregate between juveniles and adults, which frequently do not hold true when comparing individuals"; "[c]hronological age is not an unfailing measure of psychological development, and common experience suggests that many 17-year-olds are more mature than the average young 'adult"'; and "the class of offenders exempted from capital punishment [under Roper] is too broad and too diverse to warrant a categorical prohibition," which makes the rule "indefensibly arbitrary" by "protect[ing] a number of offenders who are mature enough to deserve the death penalty and may well leave vulnerable many who are not.” Id. at 601-02 (O’Connor, J., dissenting).

${ }^{53}$ Id. ("The logic of Thompson extends to those who are under 18.").

${ }^{54}$ Elizabeth C. Victor \& Ahmad R. Hariri, A Neuroscience Perspective on Sexual Risk Behavior in Adolescence and Emerging Adulthood, 28 DEVELOPMENTAL \& Psychopathology 471, 472 (2016) ("In the last decade[,] remarkable research has been conducted in the field of developmental neuroscience to provide a richer understanding of brain function and development during adolescence and emerging adulthood.”). Emerging adulthood is loosely defined as the period from late adolescence to the mid-20s. See Aude Henin \& Noah Berman, The Promise and Peril of Emerging Adulthood: Introduction to the Special Issue, 23:3 COGNITIVE \& BeHAVIORAL PRACTICE 263, 263 (2016); see also LAUREnCE SteinBerg, AdOLESCEnCE 51-58 (11 ed., 2017) (noting that adolescence is commonly defined as the second decade of life (ages 11 to 20)).

Some of the many novel developments in neuroscience in the past decade include: functional magnetic resonance imaging (fMRI) studies have become ubiquitous in the field of neuroscience, and the tools used in conducting fMRI research have become significantly more sophisticated, Kerri Smith, fMRI 2.0: Functional Magnetic Resonance Imaging Is Growing from Showy Adolescence into a Workhorse of Brain Imaging, 484 NATURE 24, 25 
Developments in neuroscience confirm that impulsivity, a tendency to engage in high-risk behavior, a strong susceptibility to peer pressure, and a high degree of personality plasticity characterize people under 18 just as they characterized the juveniles described in Miller, Graham, and Roper. ${ }^{55}$ These traits are the product of asynchronous neurological developments that are common to juveniles and people between 18 and 21: although the brain's reward centers are fully developed and primed for impulsive action, ${ }^{56}$ the regions of the brain that regulate higher reasoning and emotional control remain immature. ${ }^{57}$ Put another way, the brains of people under 21, unlike adults' brains but like teenagers' brains, are capable of

(2012) (observing that "fMRI has been applied to almost every aspect of brain science" and that in 2010, "neuroscientists used fMRI in more than 1,500 published articles"); diffusor tensor imaging (DTI), a form of MRI, has obtained more widespread clinical use and now allows neuroscientists to study white matter integrity in real time with a heightened degree of sensitivity, thereby giving scientists and clinicians access to more detailed information about how the brain develops, Megan K. Horton et al., Neuroimaging Is a Novel Tool to Understand the Impact of Environmental Chemicals on Neurodevelopment, 26 CURRENT OPINIONS IN PEDIATRICS 230, 231-32 (2014) (describing DTI and other "[r]ecent advances in neuroimaging techniques" that have "opened unprecedented access to study the developing human brain”); and neuroscientists have developed experimental tools like resting-state functional connectivity magnetic resonance imaging (RS-fcMRI), which allow them to identify specific regions of the brain that control brain development, Benjamin J. Shannon et al., Premotor Functional Connectivity Predicts Impulsivity in Juvenile Offenders, 27 ProceEdings of the NATIONAL ACADEMY of SCIENCE 11241 (2014) (describing RS-fcMRI studies as "rapidly emerging as a major theme of human imaging research" and applying that tool to study how young people's brains develop).

55 Compare Henin \& Berman, supra note 54, at 264-65 (describing emerging adulthood as a developmental stage defined by high-risk behavior, vulnerability to peer pressure, impulsivity, deficits in self-regulation, and ongoing neurological growth) with Miller, 567 U.S. at 477 (describing the "hallmark features" of adolescence including "immaturity, impetuosity, and failure to appreciate risks and consequences").

56 The limbic system, responsible for emotion processing, social information processing, and reward appraisal; matures around the time of puberty. E.g., STEINBERG, supra note Error! Bookmark not defined., at 51-58; Daniel Romer, Valerie F. Reyna \& Theodore D. Satterthwaite, Beyond Stereotypes of Adolescent Risk Taking: Placing the Adolescent Brain in Developmental Context, 27 Developmental Cognitive NEUROSCIENCE 19, 19-21 (2017). Changes in the limbic system during adolescence are associated with adolescents becoming more emotional, more sensitive to stress, more sensitive to rewards, and more likely to engage in sensation-seeking. STEINBERG, supra note Error! Bookmark not defined., at 55-56.

${ }^{57}$ The prefrontal cortex allows people to engage in sophisticated thinking like planning and weighing risks and rewards. Lawrence Steinberg, Adolescent Development and Juvenile Justice, 5 Ann. Rev. Clinical Psychol. 459, 466 (2009). This region of the brain is last to mature and is not fully developed until the mid-twenties. STEINBERG, supra note Error! Bookmark not defined., at 60; B.J. Casey, S Getz, A Galvan, The Adolescent Brain. 28 DEV. REV. 62 (2008); J Giedd, Structural Magnetic Resonance Imaging of the Adolescent Brain, 1021 Ann. N. Y. Acad. Sci. 77 (2004); Lawrence Steinberg, A Neurobehavioral Perspective on Adolescent Risk-Taking, 28 Dev. Rev. 78 (2008). 
triggering adult emotions but are not capable of managing or processing those emotions.

During the late teens and early 20s, a young person's brain is undergoing rapid changes in the areas of the brain most closely connected to impulsivity and decision-making. ${ }^{58}$ Specifically, recent neuroimaging studies show that the volume of white matter in the brain is relatively stable until around age 21, when it begins to increase dramatically. ${ }^{59}$ That is important because white matter fibers transmit information between neurons, allowing different regions of the brain to communicate with each other. In practice, this means that the brains of people under 21 are poorly integrated. $^{60}$ Additionally, increased white matter volume in the frontolimbic system - a part of the brain that is not fully developed until after age 21-enables individuals to modulate anxiety, deal with fear, and become socially adept. Because of these developmental deficits, people under 21 have difficulty generating appropriate responses to fear,

\footnotetext{
58 See Lars T. Westlye et al., Life-Span Changes of the Human Brain White Matter: Diffusion Tensor Imaging (DTI) and Volumetry, 20 CEREBRAL CORTEX 2055, 2062 (2010). The specific changes involve the development of "association cortices and the frontolimibc systems involved in executive, attention, reward, and social processes." Bradley TaborThomas \& Korlay Pérez-Edgar, Emerging Adult Brain Development, in THE OXFORD HANDBOOK of EMERging Adulthood 2 (Jeffrey Jensen Arnett, ed. 2015). And those developments are "primarily expressed in axonal myelination and gray matter pruning, with a reduction in the cortical thickness and a simultaneous increase in white matter volume." Knežević \& Marinković, supra, at 107. These changes have practical effects that are borne out by laboratory studies. For example, fMRI studies of adults' brains show that when adults engage in response inhibition trials-common laboratory tests designed to evaluate impulsivity - a handful of brain regions are activated. Adam R. Aron, From Reactive to Proactive and Selective Control: Developing a Richer Model for Stopping Inappropriate Responses, 69 BIOL. PSYCH. 55, 60-63 (2011). When those same tests are given to young people in their late teens and early 20s, however, the same brain regions are not activated in the same way. Martina Knežević \& Ksenija Marinković, Neurodynamic Correlates of Response Inhibition from Emerging to Mid Adulthood, 43 CoGNITIVE DEV. 106 (2017). Rather, young adults in their late teens and early 20s-unlike their older adult counterparts - perform worse on laboratory impulsivity tests. Id. at 109-10, 114-15.

${ }^{59}$ Westlye, supra note 58, at 2062.

60 Tabor-Thomas \& Pérez-Edgar, supra note 58, at 9. In one study designed to test the real-world impacts of an underdeveloped frontolimbic system, researchers asked teenagers, emerging adults (defined in the study as people ages 18 to 21), and young adults in their mid-20 to exercise impulse control under emotionally neutral and emotionally arousing conditions. Alexandra O. Cohen et al., When is an Adolescent an Adult? Assessing Cognitive Control in Emotional and Nonemotional Contexts, 27 PSYCHOLOGICAL SCI. 54962 (2016). Although emerging adults performed similarly to young adults in response to emotionally neutral cues, that pattern flipped in response to threatening cues: emerging adults performed like teenagers and their brain activity looked like that of teenagers, not adults. Id. at 556-57.
} 
envisioning the future, and understanding consequences. ${ }^{61}$

The brains of people under 21, like those of people under 18, also remain immature in three areas that support self-control and emotional regulation: the amygdala, the prefrontal cortex, and the ventral striatum. ${ }^{62}$ For example, new neuroimaging studies confirm that the prefrontal cortex -an area of the brain associated with reasoning and higher function-remains developmentally immature and underregulated until the mid-20s, while the brain's dopamine-producing reward centers are relatively overexpressed, making young adults "more vulnerable to impulsivity," less capable of emotional reasoning, and more likely to make "errors in self-regulation." 63 Similarly, fMRI studies indicate that the brains of people in their late teens and early 20s lack the structural development that is necessary for higher level reasoning and emotional regulation. ${ }^{64}$

The differing timetables of brain development-increased rewardseeking, "which occurs early and is relatively abrupt," and the increase in self-regulatory competence, "which occurs gradually and is not complete until the mid-20s" - makes the period from the late teens to the early 20s "a time of heightened vulnerability to risky and reckless behavior." 65 The heightened propensity for recklessness is borne out in an increased risk of negative outcomes for individuals under 21. For example, the peak risk years for both committing and being a victim of homicide are 19 and $20,{ }^{66}$ and people in their late teens and early twenties have higher rates of alcohol and illicit drug use, unplanned pregnancy, and sexually transmitted

${ }^{61}$ Tabor-Thomas \& Pérez-Edgar, supra note 60, at 9.

${ }^{62}$ B.J. Casey, Beyond Simple Models of Self-Control to Circuit-Based Accounts of Adolescent Behavior, 66 AnNuAl ReV. OF Psychology 295, 300 (2015).

${ }^{63}$ Henin \& Berman, supra note 55, at 264-65; B.J. Casey, Sarah Getz \& Adriana Galvan, The Adolescent Brain. 28 Developmental Rev. 62, 63 (2008) (describing increased adolescent sensation-seeking behavior); Elizabeth Cauffman, Arrested Development: Adolescent Development \& Juvenile Justice, TEDx TALKS (2016), https://www.youtube.com/watch?v=wUa0bIqZ0XU (explaining why young people are driven to take risks without considering the consequences).

${ }^{64}$ Nitin Gogtay et al., Dynamic Mapping of Human Cortical Development During Childhood Through Early Adulthood, 101:21 PROCEEDINGS OF THE NATIONAL ACADEMY OF SCIENCE 8174 (2004) (demonstrating that the volume of cortical grey matter-neuronal cell bodies-in areas of the brain critical to integrating higher thought processing does not peak until the mid-20s).

${ }^{65}$ Laurence Steinberg, A Social Neuroscience Perspective on Adolescent Risk-Taking, 28 Dev. ReV. 78, 83 (2008); Renata L.E.P. Reniers et al., Is it all in the Reward? Peers Influence Risk-Taking Behaviour in Young Adulthood, 108 BRIT. J. PsYCH. 276, 277 (2017) ("[Although] [i]t is often overlooked ... adolescents and young adults have been shown to be equally susceptible to taking risks.”).

${ }^{66}$ Rolf Loeber \& David P. Farrington, Young Male Homicide Offenders and Victims, in Young Homicide OfFenders \& Victims (Rolf Loeber \& David P. Farrington, eds. 2011). 
infections than any other age group. ${ }^{67}$

Researchers have proposed that this spike in risky behavior is a product of two defining, class-wide characteristics of people under 21. On the one hand, their brains are physiologically like those of younger children, unable to fully regulate emotion or evaluate risk. On the other hand, they are experiencing rapid changes in social control, with the end of high school and the beginning of college or employment. ${ }^{68}$ These neuropsychological and social developments are accompanied by meaningful personality changes. Specifically, recent studies show that people in their late teens and early 20s have a "sensitivity to environmental factors in terms of the stability of personality features during this phase" and a unique plasticity of character that fades as they reach their mid-20s. ${ }^{69}$ These factors also mean that people in their late teens and early twenties are uniquely susceptible to peer pressure. ${ }^{70}$

In short, people under 21 display the same traits that the Court identified in Atkins, Roper, and Miller as diminishing blameworthiness and undermining the case for retributive punishment: compared to adults, young people under 21, like juveniles and people with intellectual disability, have diminished capacities "to abstract from mistakes and learn from experience, to engage in logical reasoning, to control impulses, and to understand the reactions of others." 71 They have a "lack of maturity and an underdeveloped sense of responsibility" that "often result in impetuous and ill-considered actions and decisions," they are "more vulnerable or susceptible to negative influences and outside pressures, including peer pressure," and their characters are "not as well formed" and their personalities "more transitory, less fixed" than those of adults. ${ }^{72}$

These traits, in turn, "render suspect any conclusion that a [person under

${ }^{67}$ Henin \& Berman, supra note63, at 264.

68 See STEINBERG, supra note 54, at 55-56; Tabor-Thomas \& Pérez-Edgar, supra note 60 , at 18.

${ }^{69}$ Adriel Boals, Shana Southard-Dobbs, \& Heidemarie Blumental, Adverse Events in Emerging Adulthood Are Associated with Increases in Neuroticism, 83 J. PERSONALITY 202, 203 (2015).

${ }^{70}$ Reniers et al., supra note 65, at 277-78. Studies show that risk-taking behavior is more frequent and more risky when a person in the 18 to 21-year age range is around peers or older adults, and multiple studies have concluded that the presence of peers or older adults heightens a young person's sensitivity to the potential brain-chemical reward value of risky decisions. Id. at 277. Again, underlying neurophysiological developments may help explain this: risky behavior in the company of peers is correlated with increased activation of reward-related brain regions like the ventral striatum and orbitofrontal cortex, regions that are relatively overdeveloped in people ages 18 to 21 . Id.

${ }^{71}$ Atkins, 536 U.S. at 318.

${ }^{72}$ Roper, 543 U.S. at 569-70 (quoting Johnson v. Texas, 509 U.S. 350, 367 (1993)). 
21] falls among the worst offenders." 73 As the Court has explained, unless the imposition of the death penalty on a particular class of offender measurably contributes to the penological justifications for capital punishment-retribution and deterrence- "it is nothing more than the purposeless and needless imposition of pain and suffering, and hence and unconstitutional punishment. ${ }^{74}$ Executing youthful offenders serves neither goal.

Retribution is "the oldest theory of punishment" and "is imposed by society on criminals in order to obtain revenge."75 In the context of capital punishment, retribution is a valid justification only for "a narrow category of the most serious crimes" committed by the most culpable offenders. ${ }^{76}$ Thus, once we recognize that youthful offenders have a diminished culpability because their brains are not fully developed, "it is evident that the penological justifications for the death penalty apply to them with lesser force than to adults."

"With respect to deterrence- - the interest in preventing capital crimes by prospective offenders-'it seems likely that capital punishment can serve as a deterrent only when a murder is the result of premeditation and deliberation." " 77 As described above, new scientific research shows that people ages 18 to 21, like people under 18 , are prone to act on impulse rather than premeditation. Thus, the likelihood that a person under 21 "has made the kind of cost-benefit analysis that attaches any weight to the possibility of execution is so remote as to be virtually nonexistent." 78

In sum, post-Roper scientific research confirms the common-sense impression that people under 21 are less morally culpable than their adult counterparts because their brains are physiologically immature at least until the age of 21. Their reduced culpability removes them, as a class, from the group of defendants that can reliably be considered the worst of the worst.

\section{B. Society's Treatment of People Under 21}

Society treats people under 21 more like teenagers than adults, acknowledging — at least tacitly - the fact that brain development is not complete by the age of 18. In Roper, the Court looked to age restrictions in various state laws unrelated to capital sentencing and concluded that states' prohibitions on "voting, serving on juries, or marrying without parental

\footnotetext{
${ }^{73} \mathrm{Id}$. at $570-71$.

${ }^{74}$ Atkins, 536 U.S. at 319 (quoting Enmund, 458 U.S. at 798).

${ }^{75} 1$ W. LaFave, Subatantive Criminal Law § 1.5(a)(6) (2d ed. 2017).

${ }^{76}$ Atkins, 536 U.S. at 319.

${ }^{77}$ Id. (quoting Endmund, 458 U.S. at 799).

${ }^{78}$ Thompson, 487 U.S. at 837.
} 
consent" were indications that states recognized "the comparative immaturity and irresponsibility of juveniles." 79 Those same kinds of restrictions exist for people under the age of $21 .^{80}$ Significantly, many of the restrictions on people under 21 have been adopted in the wake of Roper, as society's perceptions of youth have evolved.

For example, all 50 states and the District of Columbia impose a minimum age restriction of 21 years for the consumption, purchase, or possession of alcohol or recreational marijuana. ${ }^{81}$ Over 425 cities and counties in 22 states now prohibit the sale of tobacco to people under $21 .^{82}$ Forty-one states impose a minimum age of 21 to obtain concealed carry permits for firearms, ${ }^{83}$ and federal law prohibits licensed gun dealers from selling handguns and ammunition to people under the age of $21 .{ }^{84}$ Federal immigration law permits a parent of a U.S. citizen to petition for an immigrant visa for any "unmarried children under the age of 21," 85 but a child can only petition for an immigrant visa for his or her parents if the child is at least $21 .{ }^{86}$ Notably, these restrictions are all categorical: none of these laws permit a 21-year-old to engage in the prohibited behavior if they can make an individualized showing of maturity.

Further recognizing brain development continues into the 20s, most rental car companies will not rent to drivers under the age of 21 and apply added fees for drivers under the age of $25 .{ }^{87}$ Only two states, Michigan and

79543 U.S. at 569.

${ }^{80}$ It is also worth noting that there is a social and moral difference between affirmative rights to engage in adult conduct and the negative right to not be subjected to adult punishment. This is because, as one scholar has explained, "[u]nlike other laws that regulate behavior, criminal punishment involves finding people morally blameworthy,” and the "defining characteristic" of criminal punishment is "state censure." Thus, not extending Roper to people over 18 "overlook[s] the important and unique goals for imposing criminal punishment of treating equally culpable offenders equally and making individualized inquires of culpability for society's harshest punishments.” Kelsey B. Shust, Extending Sentencing Mitigation for Deserving Young Adults, 104 J. CRIM. L. \& CRIMINOLOGY 667, 691 (2014).

81 National Institute on Alcohol Abuse And Alcoholism, State Profiles of Underage Drinking laws (last visited Nov. 2, 2018), https://alcoholpolicy.niaaa.nih.gov/underage-drinking/state-profiles; NATIONAL Conference OF StATE LegisLAtUres, State Medical Marijuana Laws (Oct. 17, 2018), http://www.ncsl.org/research/health/state-medical-marijuana-laws.aspx.

82 Tobacco21, https://tobacco21.org/state-by-state/ (last visited Jan. 18, 2019).

${ }^{83}$ Data set on file with authors.

${ }^{84}$ See 18 U.S.C. § 922(b)(1), (c)(1); 27 C.F.R. § 478.99(b).

858 U.S.C. $\S 1151(\mathrm{~b})(2)(\mathrm{A})(\mathrm{i})$.

${ }^{86}$ In re Hassan, 16 I. \& N. Dec. 16, Interim Dec. 2531, 1976 WL 32325 (B.I.A. 1976).

87 See e.g., Alamo, https://www.alamo.com/en_US/car-rental-faqs/agerequirements.html (last visited Jan. 24, 2019); Dollar, https://www.dollar.com/AboutUs/GeneralPolicies.aspx\#DrivingAge (last visited Jan. 24, 
New York, require rental car companies to rent to drivers age 18 and over. ${ }^{88}$ State and federal laws impose categorical age-of-candidacy requirements for individuals seeking public office. For example, the U.S. Constitution prohibits individuals under the age of 25 from running for the House of Representatives, ${ }^{89}$ and 27 states prohibit individuals from running for lower-house office before the age of $21 .{ }^{90}$

A 2014 report from the United States Department of Justice recommended that legislators raise the age for criminal court to at least twenty-one, in light of the fact that "young adult offenders ages 18-24 are, in some ways, more similar to juveniles than to adults." ${ }^{11}$ Notably, these restrictions are all categorical: none of these laws permit a 21-year-old to engage in the prohibited behavior if they can make an individualized showing of maturity. These laws provide further support for increasing the cutoff for execution to at least 21 years old.

\section{DeAth SeNTENCES AND ExeCutions of YouthFul OfFenders SinCE ROPER}

Roper's evolving-standards analysis began with a count of states that abolished the death penalty for all offenders, as a baseline measure against which the Court could compare juvenile offenders. ${ }^{92}$ We adopt that same analysis here. Between 2005 and 2018, the number of states with the death penalty decreased. Specifically, twenty states and the District of Columbia legislatively abolished or overturned the death penalty, eight more than when Roper was decided twelve years ago, ${ }^{93}$ and the governors of three additional states imposed moratoria on executions. ${ }^{94}$ In twenty-three states,

2019); Enterprise, https://www.enterprise.com/en/help/faqs/car-rental-under-25.html (last visited Jan. 24, 2019); Hertz https://www.hertz.com/rentacar/misc/index.jsp?targetPage=Hertz_Renting_to_Drivers_Un der_25.jsp (last visited Jan., 24, 2019).

${ }^{88}$ N.Y. Gen. Bus. Law § 396-z (McKinney); Bickham v. Hertz Rent-a-Car, MDCR No. 113521-PA32 (2000).

${ }^{89}$ U.S. Const. Art. I § 2 cl. 2.

${ }^{90}$ Data set on file with authors.

${ }^{91}$ U.S. Dep't of Justice, Office of Justice Programs, National Institute of Justice, Young Offenders: What Happens and What Should Happen, Doc. No. NCJ 242653, at 2 (Feb. 2014).

${ }^{92}$ Roper, 543 U.S. at 564-65.

${ }^{93}$ States that abolished the death penalty post-Roper (and did not bring it back) and the year of abolition are: New York (2007); New Jersey (2007); New Mexico (2009); Illinois (2011); Connecticut (2012); Maryland (2013); Delaware (2016); Washington (2018). Death Penalty Information Center, States With and Without the Death Penalty, https://deathpenaltyinfo.org/states-and-without-death-penalty (Nov. 2, 2018).

${ }^{94}$ The governor of Pennsylvania imposed moratoria on the death penalty in 2015. The 
then, people under twenty one are categorically protected from execution. Even before taking account of actual sentencing practices, that number is greater than in Graham and is greater than in Miller, where the Court nevertheless found national consensuses. ${ }^{95}$ Furthermore, the fact that a particular sentence is an available option is not reliable evidence against the existence of a consensus if the states that authorize the penalty never impose it. Those states "should not be treated as if they have expressed the view that the sentence is appropriate." 96

When the Court identifies a national consensus, it does so based "not so much the number of the States ...., but the consistency and the direction of the change." 97 Accordingly, "actual sentencing practices are an important part of the Court's inquiry into consensus." 98 Thus, in order to determine whether there is a national consensus against the execution of youthful offenders, our analysis began with trends in the number of states sentencing youthful offenders to death per year, the number of death sentences of youthful offenders per year, and the number of executions of youthful offenders per year. Based on prior research identifying racial disparities in sentencing juvenile and young defendants, ${ }^{99}$ we also reviewed our data to determine whether there is evidence of racial disparity in the sentencing of youthful offenders.

This article discusses both sentencing decisions and actual executions because a decline in the number of actual executions of young offenders relative to the number of death sentences is also an indication of whether juries, state courts, and members of the executive branch are increasingly unwilling to see a death sentence imposed on a young offender. When examining the executions, it is important to note the length of time between a death sentence and an execution. Across the country, there are significant lags from when a sentence of death is announced to when the sentence is carried out. For example, in 2013, the most recent year for which accurate data is available, the average time between sentencing and execution in the

governor of Oregon extended that State's moratorium in 2015. And in 2013, the governor of Colorado granted an indefinite stay of execution to the only one of the State's three death row inmates who was facing imminent execution. DEATH PENALTY INFORMATION CENTER, Statements from Governors of Pennsylvania, Washington, Colorado, and Oregon Halting Executions, https://deathpenaltyinfo.org/node/5792 (2017).

95 See Graham, 560 U.S. at 62 (noting that 37 states plus the District of Columbia permitted life without parole sentences for juvenile nonhomicide offenders but nevertheless finding a consensus); Miller, 567 U.S. at 482-83 (noting that 28 States plus the District of Columbia required life without parole for some juvenile homicide offenders but nevertheless finding a consensus).

96 See Graham, 560 U.S. at 67.

${ }^{97}$ Atkins, 536 U.S. at 315.

${ }^{98}$ Graham, 560 U.S. at 62.

${ }^{99}$ See infra Notes 
United States was 186 months (or 15.5 years). ${ }^{100}$ Thus, on average, a sentencing decision reached in 2005 when Roper issued would not be carried out until approximately 2020. ${ }^{101}$ Due to the delay between sentencing and execution, sentencing decisions since Roper likely present a more accurate picture of society's view of the mitigating impact of youth than the number of executions of young people in that same time frame.

\section{A. Methodology}

To determine sentencing and execution practices for offenders in the 18-20 year old range, we developed a database with every death sentence and execution across the country between 2005 and 2017. Execution data for all of the relevant years, including the individual's name, race, and jurisdiction of execution, were available from The Death Penalty Information Center, ${ }^{102}$ as were death sentencing data beginning in 2012. ${ }^{103}$ Prior to 2012, we identified individuals sentenced to death by comparing the lists of individuals on death row in each jurisdiction as reported by the Legal Defense Fund in their quarterly Death Row USA reports. ${ }^{104}$ Using these reports, we were able to identify when an individual was added to a jurisdiction's death row, indicating a new death sentence during that time period.

Once we compiled a list of every individual sentenced to death and executed since 2005, we determined their age at the time of the crime, the offender's race and gender, the race and gender of the victim(s) (where available), and the final outcome of the case (i.e. execution, reversal resulting in a sentence of less than death, or pending). This data was compiled through vital record searches, reviewing reported judicial decisions, and searching local newspaper archives. ${ }^{105}$ We identified 1133 death sentences, 140 of which were imposed on youthful offenders (18-20 year olds). They were mostly male $(97 \%)$ and 21 years and older (88\%). The race of offenders included $41 \%$ white, $41 \%$ black, $15 \%$ Latino, $2 \%$ Asian, and 1\% Native American.

100 DeAth Penalty Information Center, Time on Death Row, https://deathpenaltyinfo.org/time-death-row (last visited Jan. 19, 2019).

${ }^{101} \mathrm{Id}$.

${ }^{102}$ See https://deathpenaltyinfo.org/views-executions.

$103 \quad$ See https://deathpenaltyinfo.org/2012-sentencing; https://deathpenaltyinfo.org/2013-sentencing; $\quad$ https://deathpenaltyinfo.org/2014sentencing; $\quad$ https://deathpenaltyinfo.org/2015-sentencing; https://deathpenaltyinfo.org/2016-sentencing; https://deathpenaltyinfo.org/2017-sentencing.

$104 \mathrm{http}: / /$ www.naacpldf.org/death-row-usa

${ }^{105}$ Our complete database is on file with the authors. 


\section{B. DeAth SENTENCING SinCE Roper}

First, we asked whether there is a national consensus against executing offenders who were under 21 by examining the number of states engaging in the practices, the number of death sentences, and the number of executions. Our data suggest there is. Since Roper, only 140 of the 1133 death sentences were imposed on youthful offenders and the number of youthful offenders sentenced to death each year has been declining. During the same period, the number of all people sentenced to death per year has declined.

Figure 1. Death Sentences by Year and Age Group

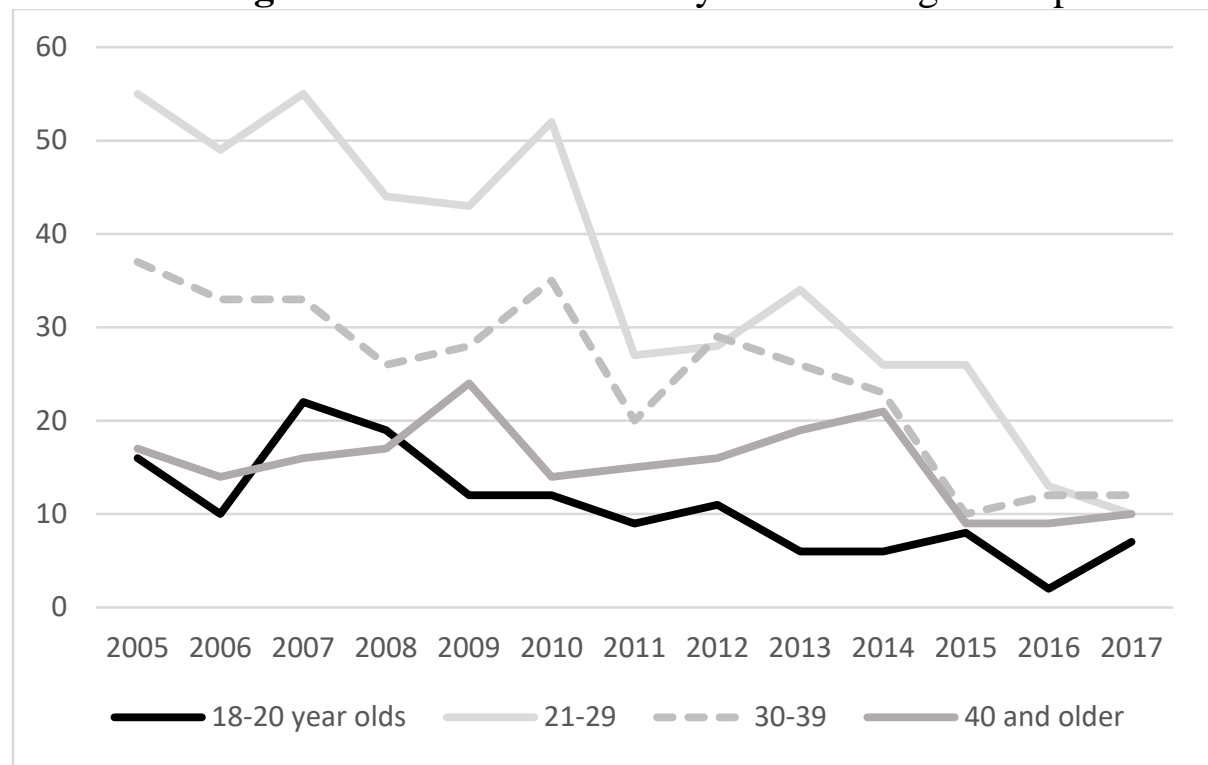

Note: The figure displays the number of death sentences imposed each year by age of the offender at the time of the crime.

As Figure 1 indicates, the proportion of death sentences given to young offenders has remained very low, even as the overall number of people sentenced to death has greatly declined since 2005. The peak for young offender death sentences post-Roper was in 2007, when twenty-two youthful offenders nationwide were sentenced to die. Since 2013, at most eight youthful offenders have been sentenced to die in one year. Moreover, since Roper, death sentences for young offenders have constituted between 6 and $18 \%$ of all death sentences. This tends to be slightly less than the portion of homicide arrests: between 2004 and 2015, 18- to 20-year-olds were $14-19 \%$ of all homicide offenders with a known age. ${ }^{106}$ This fact

106 United States Department of Justice, Federal Bureau of Investigation, 
indicates that even when youthful offenders are arrested for homicide offenses, they are increasingly unlikely to receive a death sentence when compared to older homicide offenders. The consistent downward trend in death sentencing for all age groups, including youthful offenders, suggests that there is a growing consensus exists against the death penalty nationwide.

Additionally, the rate at which people are sentenced to death relative to the number of homicide arrests has remained low since 2005. As displayed in Figure 2, the number of death sentences per 100 homicide arrests in the previous year is below 1.20 for both adult and youthful offenders between 2005 and 2016.

Figure 2. Death Sentences per 100 Homicides with Known Offenders.

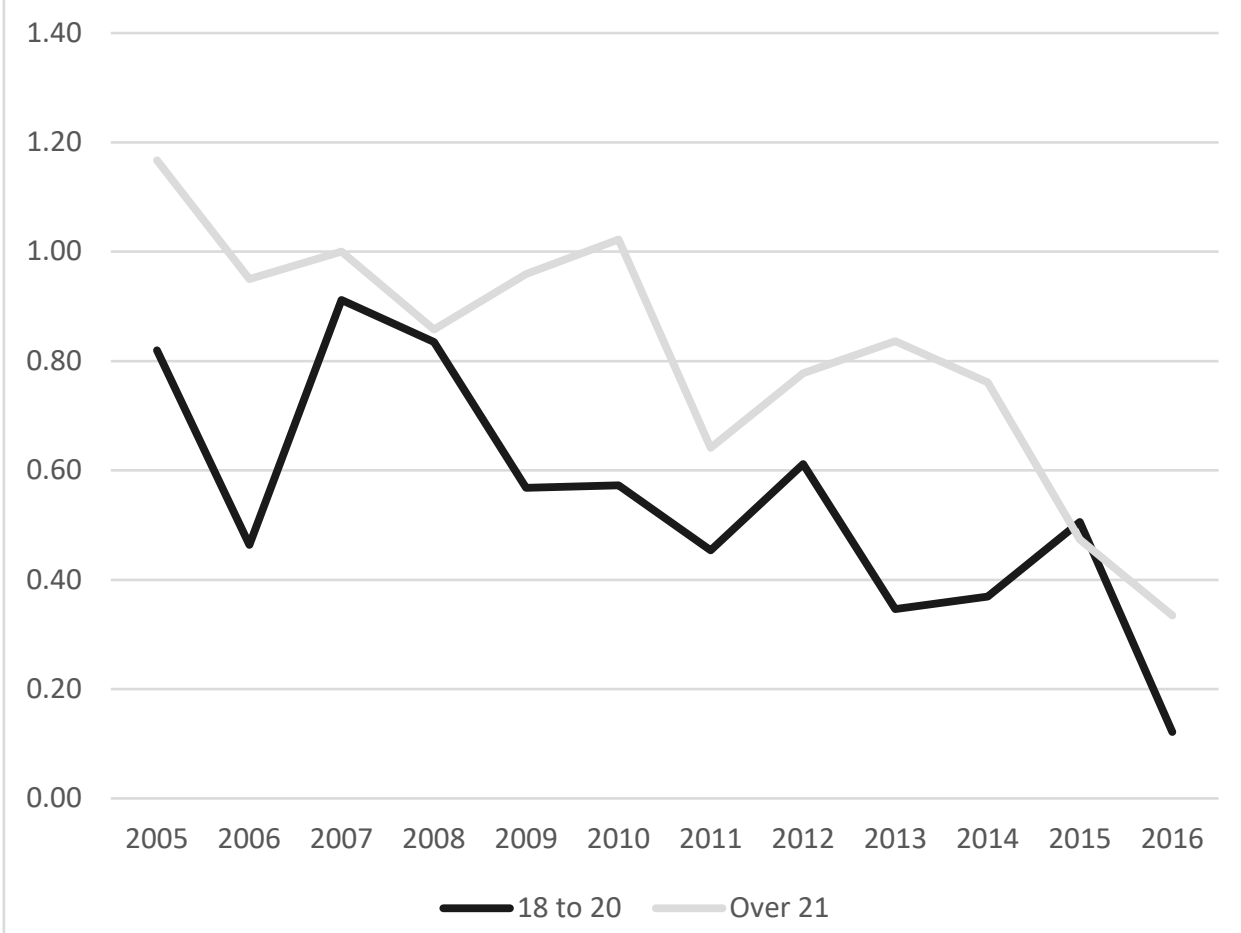

Note: The figure displays the number of death sentences imposed each year per 100 homicides with known offenders by age of the offender at the time of the crime.

Youthful offender death sentences are concentrated in a few jurisdictions. The five jurisdictions that have sentenced the most youthful

Uniform Crime Reporting Program Data: Supplementary Homicide Reports (2004-2015). As of May 2018, 2015 is the last year that homicide data is available [hereinafter Supplemental Homicide Reports]. 
offenders to death are California (34), Florida (19), Texas (15), Alabama (14), and the Federal government (8). Together these five jurisdictions make up $64 \%$ of all death sentences of youthful offenders since Roper. Twenty-nine states and the military have not sentenced a youthful offender to death since Roper, compared 20 states who have not sentenced an adult offender. Each year, this trend towards the death penalty's geographic concentration has increased, with fewer jurisdictions sentencing youthful offenders to death. As displayed in Figure 3, at the peak, in 2005 and 2007, twelve jurisdictions sentenced a person under twenty-one to death. In the last five years, at most five jurisdictions have sentenced a youthful offender to death.

Figure 3. The Number of States that Sentenced at Least One Person to Death per Year

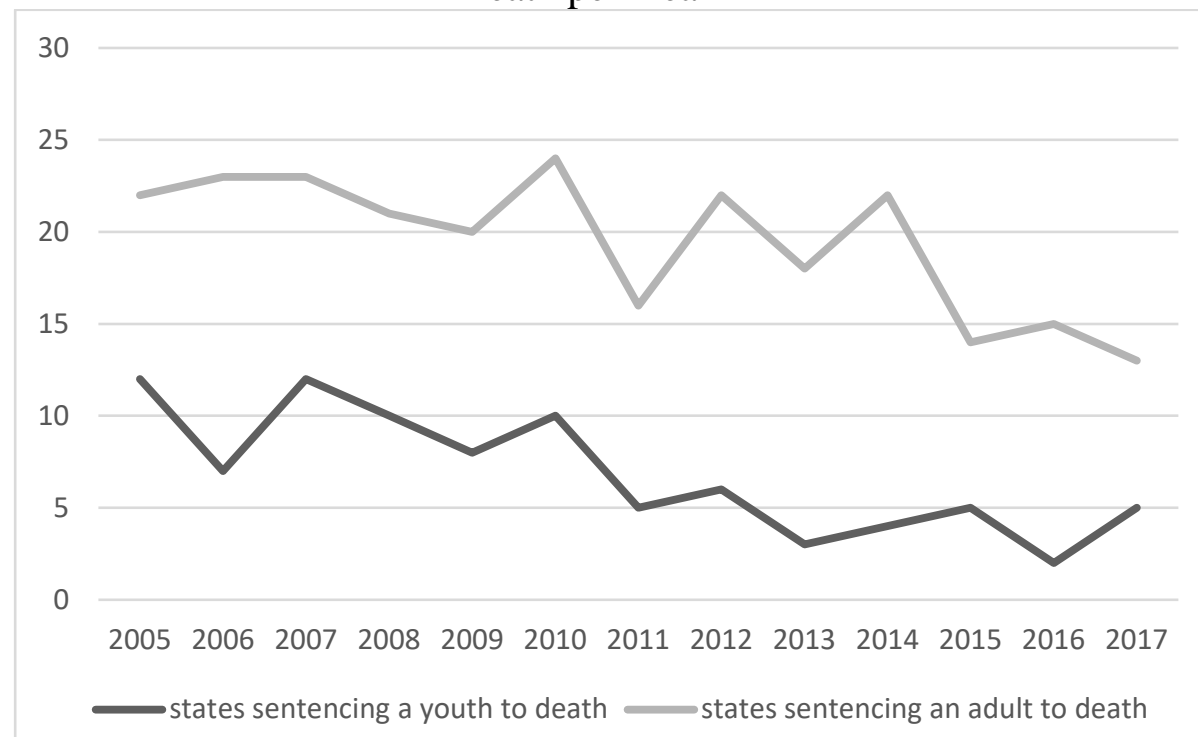

Note: The figure displays the number of states that imposed death sentences each year by age of the offender at the time of the crime.

Death sentences of youthful offenders are also concentrated in a few counties. Of the over three-thousand counties in the United States, seventyfive have sentenced a youthful offender to death since Roper. Two counties, Los Angeles and Riverside, both in California, are responsible for $15 \%$ of all death sentences of youthful offenders since Roper (11 and 10 death sentences, respectively). Together these counties make up approximately four percent of the U.S. population. ${ }^{107}$ All other counties have six or fewer

107 U.S. CENSUS BUREAU, Quick Facts (last visited May 13, 2018), https://www.census.gov/quickfacts/fact/table/US/PST045217. 
death sentences since Roper. ${ }^{108}$

\section{EXECUTIONS OF YOUTHFUL OFFENDERS SINCE ROPER}

Between 2005 and 2017, 521 people were executed in all jurisdictions in the United States; 102 (20\%) were under twenty-one at the time of their crimes. All but one of those men received their death sentences prior to Roper. ${ }^{109}$ The remaining 101 young offenders who were executed postRoper received their death sentences on average ten years before the Supreme Court decided Roper.

Like death sentencing, executions are highly concentrated in a few areas. Between 2005 and 2017, 15 states have executed a person who was under 21 at the time of his offense. Texas, with 55 executions of youthful offenders, accounted for $54 \%$ of all of the young offender executions between 2005 and 2016. ${ }^{110}$ Ohio, with 9 executions, executed the second highest number of youthful offenders since Roper. Since Roper, 35 states have not executed a youthful offender. Three of these states-Kansas, ${ }^{111}$ Idaho, ${ }^{112}$ and Kentucky ${ }^{113}$ _have had youthful offenders on their death rows. Twenty-three states have also not executed an adult since Roper.

There is a clear national consensus against executing offenders who were under 21. Since Roper, there has been a consistent downward trend in the number of states that sentence youthful offenders to die. Youthful offenders are protected from execution in 23 states, and only 13 states have handed down new death sentences to youthful offenders post-Roper. Moreover, in 30 states a youthful offender would not be executed-ten more than in Roper, 17 more than in Graham, and nine more than in Miller. Such a consistent and deepening movement away from executing a class of

108 The counties with the next highest numbers of youthful offenders include Maricopa, Arizona (6); Houston, Texas (5); and Duval, FL (5).

${ }^{109}$ But see notes Error! Bookmark not defined.-Error! Bookmark not defined. and accompanying text (describing the considerable delay between death sentences and executions).

${ }^{110}$ None of those individuals received his death sentence after Roper.

111 Jonathan Carr, 20 at the time of the offense, was sentenced in 2002. See State v. Carr, 331 P.3d 544 (Kan. 2014), reversed by Kansas v. Carr, 136 S. Ct. 633 (2016).

112 James Hairston, 20 at the time of the offense, was sentenced in 1996. State $v$. Hairston, 988 P.2d 1170 (Id. 1999); Judge Sentences Man to Death: 20-Year-Old James Hairston Killed Elderly Couple for Money, AP (Nov. 16, 1996), http://www.spokesman.com/stories/1996/nov/16/judge-sentences-man-to-death-20-yearold-james/.

113 Karu Gene White, 19 at the time of the offense, was sentenced in 1980, and Ronnie Lee Bowling, 20 at the time of the offense, was sentenced in 1992. Ronnie Lee Bowling, CAses of Suspected Miscarriages OF Justice (last visited Nov. 8, 2018), http://cases.iippi.org/ronnie-lee-bowling/comment-page-1/ 
defendant is a hallmark indication that a national consensus exists.

\section{RACIAL DisParity IN YOUTHFUl OFFENDER SENTENCING}

No review of capital sentencing would be complete without considering race effects. Based on historical indicators of racial disparities in sentencing young people, we expected to find racial disparities in our data set. The results were stark revealing that $74 \%$ of youthful offenders sentenced to death since Roper were black or Latinx.

\section{A. Historical EVIDENCE of RACIAL Disparity in the SENTENCING OF YOUNG PEOPLE}

In the pre-Furman era of capital sentencing, young black and Latino people were disproportionately sentenced to die. ${ }^{114}$ There is reason to suspect that youth of color do not receive the same consideration of their mental and emotional development. For example, black youth are overrepresented in life-without-parole sentences, and racial disparity plays a role even before the sentencing stage of a prosecution. ${ }^{115}$ At sentencing in capital cases, it is common practice for prosecutors to argue youth in aggravation when the defendant is a young person of color. ${ }^{116}$

This disparity between the severity of punishment leveled against black and Latinx youth compared to white youth is best explained by the fact that legal decision makers perceive youth of color as dangerous predators likely

114 Furman, 408 U.S. at 364 (Marshall, J., concurring) (“a look at the bare statistics regarding executions [was] enough to betray much of the discrimination . . ..”); Furman, 408 U.S. at 256-57 (Douglas, J., concurring) (“[Death sentencing schemes] are pregnant with discrimination and discrimination is an ingredient not compatible with the idea of equal protection of the laws that is implicit in the ban on 'cruel and unusual' punishments.”); see also Sheri Lynn Johnson, John H. Blume \& Hannah L. Freedman, The Pre-Furman Juvenile Death Penalty in South Carolina: Young Black Life Was Cheap, 68 S.C. L. Rev. 331, 343 (2017) (“[O]ver 80\% of all juvenile offenders executed in the United States between 1865 and 1972 were children of color.”).

${ }^{115}$ E.g., John R. Mills, Anna M. Dorn \& Amelia C. Hritz, Juvenile Life Without Parole in Law and Practice: Chronicling the Rapid Change Underway, 65 AM. U. L. REV. 535, 576 (2016) (finding that $66 \%$ of juvenile life without parole sentences are imposed on black youth).

116 See, e.g., Reply Br. for Pet'r, Tucker v. Louisiana, 136 S. Ct. 1801 (2016) (denying petition for a writ of certiorari over a dissent from Justices Breyer and Ginsburg), 2015 WL 2358360 , at $* 31-32$ (in a death penalty case involving a young offender with intellectual deficits, explaining that the prosecutor used the defendant's deficits in aggravation); see also Roper, 543 U.S. at 558 (explaining that the prosecutor in that case told the jury “Seventeen years old. Isn't that scary? Doesn't that scare you? Mitigating? Quite the contrary I submit. Quite the contrary.”). 
to recidivate, while for young white men and boys, youth is mitigating. ${ }^{117}$ One result of this institutional racial bias is that there are disproportionate percentages of black youth involved in each stage of the American juvenile justice system, from arrest, to pretrial detention, to transfers to adult court, to sentencing. ${ }^{118}$

Numerous studies have examined how race influences assessments of juveniles, their crimes, the likelihood of recidivism, and sentence recommendations. ${ }^{119}$ Research confirms that decision-makers often rely on subconscious stereotypes that black youth are more prone to criminal behavior and therefore punish them more harshly. ${ }^{120}$ Many studies have

117 See, e.g., Peter S. Lehmann, Ted Chiricos, \& William D. Bales, Sentencing Transferred Juveniles in the Adult Criminal Court: The Direct and Indirect Effects of Race and Ethnicity, 15 Youth ViOLENCE \& JuVENILE JustiCE 172, 174, 185 (2017) (reviewing past literature and, after reviewing novel multi-variate analysis, concluding that "the findings correspond with prior studies of adult offenders which have demonstrated that young Black males are sentenced more harshly than other groups”) (internal quotation omitted); Patricia Warren, Ted Chirico, \& William Bales, The Imprisonment Penalty for Young Black and Hispanic Males: A Crime-Specific Analysis, 49 J. RESEARCH IN CRIME \& DELINQUENCY 56, 61 (2012); Kareem L. Jordan \& Tina L. Freiburger, Examining the Impact of Race and Ethnicity on the Sentencing of Juveniles in the Adult Court, 21 CRIM. Justice PoliCy ReV. 186, 187-88 (2010); Darrell Steffensmeier, Jeffery Ulmer, \& John Kramer, The Interactions of Race, Gender, and Age in Criminal Sentencing: The Punishment Cost of Being Young, Black, and Male, 36 CRIMINOLOGY 763, 787 (1998).

118 E.g., Eileen Poe-Yamagata \& Michael A. Jones, And Justice for Some, U.S. Department of Education, Educational Resources Information Center (2000) (finding that in 1997-98, black youth comprised $15 \%$ of the population under 18 , but were $26 \%$ of youth arrests, $31 \%$ of referrals to juvenile court, $44 \%$ of those detained pretrial, $46 \%$ of those waived to adult court, and $58 \%$ of juvenile inmates in adult prison). See also Nancy Rodriguez, The Cumulative Effect of Race and Ethnicity in Juvenile Court Outcomes and Why Preadjudication Detention Matters, 47 J. RES. CRIME \& DELINQ. 391, 393 (2010) (stating that sentencing reflects an accumulation of bias across multiple court outcomes that compound to amplify the bias at sentencing).

119 See, e.g., Sandra Graham \& Brian S. Lowery, Priming Unconscious Racial Stereotypes About Adolescent Offenders, 28 L. \& HuM. BEHAV. 483 (2004); Phillip Atiba Goff, Matthew Christian Jackson, Brooke Allison, Lewis Di Leone, Carmen Marie Culotta, \& Natalie Ann DiTomasso, The Essence of Innocence: Consequences of Dehumanizing Black Children, 106 J. PERSONALITY \& SOC. PSYCHOL. 526 (2014).

120 George S. Bridges \& Sara Steen, Racial Disparities in Official Assessments of Juvenile Offenders: Attributional Stereotypes as Mediating Mechanisms, 63 AM. SoC. REV. 554, 555 (1998); see also George S. Bridges \& Sara Steen, Racial Disparities in Official Assessments of Juvenile Offenders: Attributional Stereotypes as Mediating Mechanisms, 63 AM. Soc. REV. 554, 561 (1998) (examining 233 narrative reports by probation officers and finding that reports were more likely to include negative internal attributions about black youth (mean =.56) compared to white youth (mean = -0.7). In addition, they were more likely to include negative external attributions about white youth (mean $=1.13$ ) compared to black youth (mean $=.75)$ (negative scores indicate positive characteristics)).

Disproportionally harsh treatment of black youth in areas outside the criminal justice 
found that black and Latinx defendants receive longer prison sentences. ${ }^{121}$ For example, a meta-analysis of 71 academic studies found that black criminal defendants received sentences that were statistically significantly harsher than white defendants. ${ }^{122}$

system also indirectly impact sentencing. Recent studies have shown that black students are more likely to be disciplined in school when the decision of whether or not to engage disciplinary processes is discretionary. BREAKING SCHOOL RULES, supra, at 42 (finding that African American high school students were disproportionately punished for discretionary offenses and were nearly three times as likely to receive a suspension for their first violation). This can have collateral consequences, as a student who has been suspended or expelled is almost ten times more likely than his or her peers to come into contact with the criminal justice system. COUNCIL OF STATE GOVERNMENTS JUSTICE Center \& TeXas A\&M University Public Policy Research Institute, Breaking SCHOOLS' RULES 66 (2011). For a student of color with a disability, the risk of being channeled into the criminal justice system is at its height: students of color with disabilities are disproportionately "deprived of an appropriate education that could have changed their School-to-Prison Pipeline trajectory.” NATIONAL COUNCIL ON DisABILITY, BREAKING THE SCHOOL-TO-PRISON PIPELINE FOR STUDENTS With DisABILITIES 5 (June 18, 2015). For example, African American students with disabilities represent 18.7 percent of the population receiving aid under federal disability laws, but 49.9 percent of students receiving that aid in correctional facilities are African American. BREAKING THE SCHOOLTO-PRISON PIPELINE, supra, at 11.

${ }^{121}$ E.g., Cassia Spohn \& Jerry Cederbloom, Race and Disparities in Sentencing: A Test of the Liberation Hypothesis, 8 JusT. Q. 305 (1991) (finding that race had an indirect effect on sentence length-black defendants were more likely to be detained before trial and were more likely to be tried by a jury, and both of these factors predicted increased sentence length — but failing to identify a direct effect of race on sentence length); Darrell Steffensmeier \& Stephen Demuth, Ethnicity and Sentencing in U.S. Federal Courts: Who Is Punished More Harshly?, 65 Am. Sociological Rev. 705 (2000) (finding that white defendants received shorter sentences compared to black and Hispanic defendants in a sample of cases under the federal sentencing guidelines); Darrell Steffensmeier \& Stephen Demuth, Ethnicity and Judges' Sentencing Decisions: Hispanic-White-Black Comparisons, 39 CRIMINOLOGY 145 (2001) (finding that Hispanic defendants received the harshest penalties in a sample of Pennsylvania cases); Jeffrey T. Ulmer \& Brian Johnson, Sentencing in Context: A Multilevel Analysis, 42 CRIMINOLOGY 137 (2004) (using hierarchical modeling to examine cases in Pennsylvania and finding that black and Hispanic defendants received longer sentences overall and were even more likely to receive longer sentences in counties with high percentages of members of their race).

${ }^{122}$ Omar Mitchell, A Meta-Analysis of Race and Sentencing Research: Explaining the Inconsistencies, 21 J. QUANTITATIVE CRIMINOLOGY 439, 454 (2005) (finding 76\% of nonfederal data indicate that black defendants are sentenced more harshly than white defendants). While this effect was reliably significant, it was also small and variable. Id. (finding a "tremendous amount of variability" in non-federal data). A few studies have found that race does not significantly influence the sentence length. E.g., Benjamin Steiner, The Effects of Juvenile Transfer to Criminal Court on Incarceration Decisions. 26 JUST. Q. 77, (2009); Cassia Spohn \& David Holleran, The Imprisonment Penalty Paid by Young Unemployed Black and Hispanic Male Offenders, 38 CRIMINOLOGY 281, 291 (2000) (examining defendants 17 years and older in Chicago, Miami, and Kansas City and finding that young black and Hispanic males are more likely to be sentenced to prison, but finding 
In short, psychological research on the effects of race in sentencing confirms that race plays a significant role at all stages of a criminal prosecution. In the context of capital sentencing, we expected to see that white but not black or Latinx criminal defendants benefit from the mitigating effects of youths. Our analysis of our data set confirms this prediction.

\section{B. RACIAL DisParity In YouthFul OfFENDER DEATH SENTENCES AND EXECUTIONS SINCE ROPER}

Using our data set, we examined whether death sentences and executions of youthful offenders are disproportionately imposed on people of color. As displayed in Figure 4, the racial composition of people sentenced to death who are under 21 is very different from the composition of people sentenced to death who are 21 and older. This difference is significant, two-sided Fisher's Exact test, $p=0.0002 .{ }^{123}$ More specifically, $25 \%$ of youthful offenders are white and $74 \%$ are black or Latinx. A higher portion of adult offenders are white, $43 \%$ compared to black and Latinx (54\%).

no effect on the length of the sentence). The different findings may be caused by the variables used in the statistical models. For example, black defendants are more likely to receive pretrial detention, and people who receive pretrial detention are less likely to be released (causing an indirect effect of race on sentencing). E.g. Spohn \& Cederbloom, supra note Error! Bookmark not defined..

${ }^{123}$ This remains significant when the groups are collapsed into the binary variable of white or people of color, $\chi^{2}(1, N=1133)=16.24, p<0.0001$. 
Figure 4. Death sentences by race and age at Crime, 2005-17.

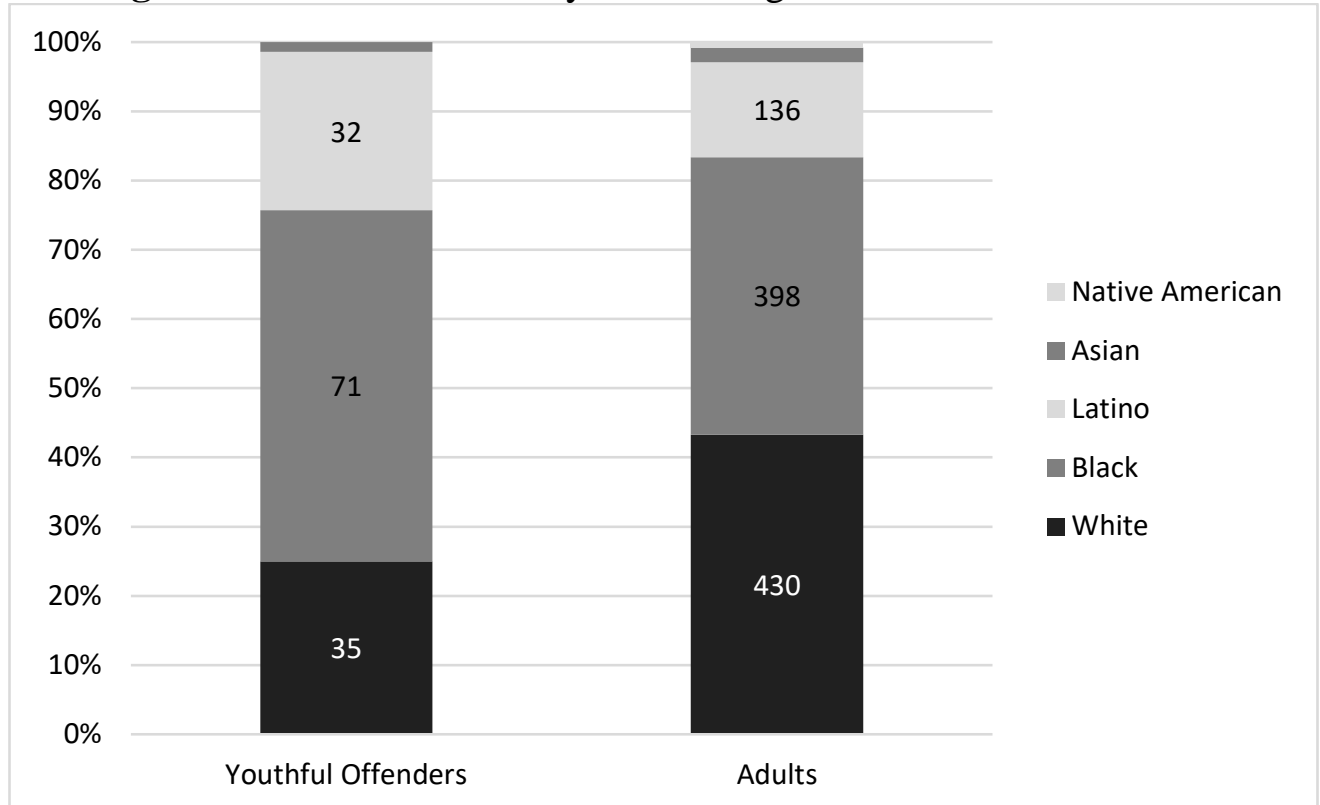

Note: The figure displays the percentage of death sentences by offender race and age at the crime (counts are reported in the cells). These include 140 youthful offender cases and 993 adult offender cases. Asian and Native American offenders make up less than three percent of death sentences in both age groups.

As with death sentencing, we also found differences in the racial composition of executions of youthful and adult offenders. As displayed in Figure 5, the racial composition of youthful offenders and adult offenders who are executed is significantly different. ${ }^{124}$ Black and Latinx youth are overrepresented in executions of youthful offenders (46\% and $16 \%$, respectively), compared to adult offenders (32\% and 11\%, respectively).

124 Fisher's Exact test, $p=0.008$ This remains significant when the groups are collapsed into white or people of color, $\chi^{2}(1, N=521)=9.78, p=0.002$. 
Figure 5. Executions by Offender Race and Age at Crime in 2005-2017.

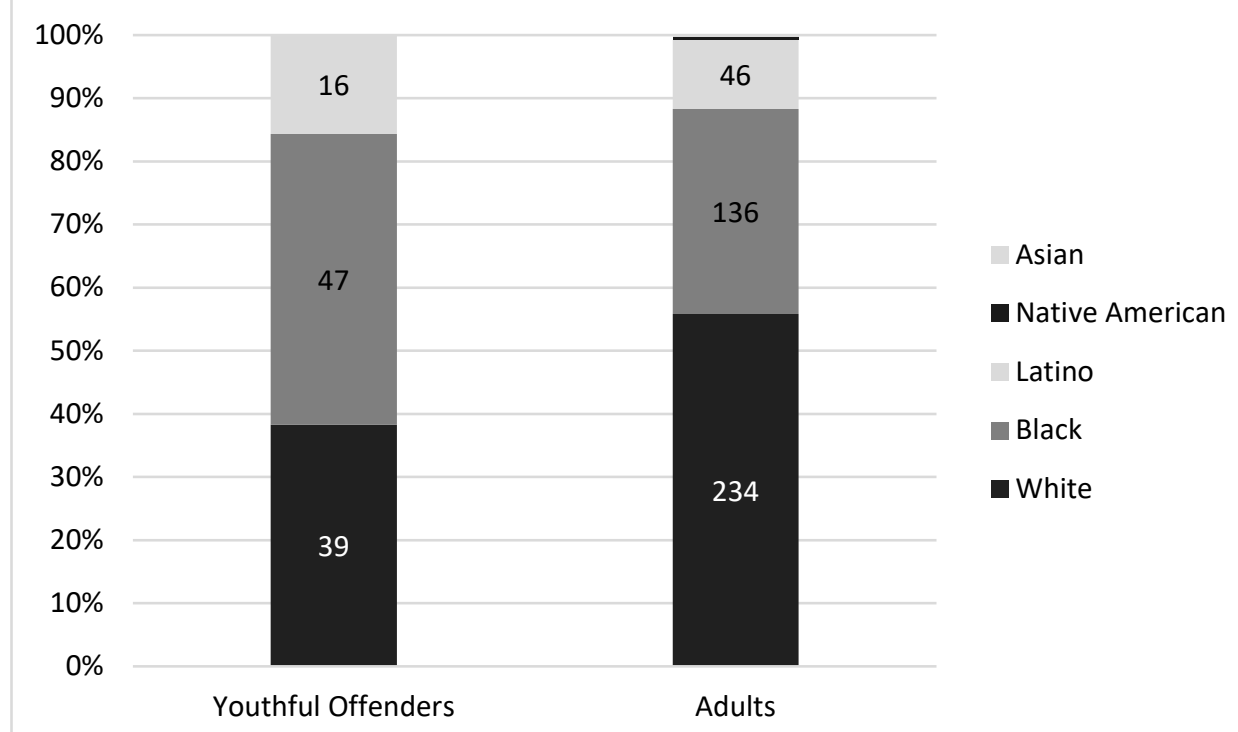

Note: The figure displays the percentage of executions by offender race and age at the crime (counts are reported in the cells). These include 102 youthful offender cases and 419 adult offender cases. There were two executions of Native American people and one execution of an Asian person, all of whom were over 21 at the time of the crime.

The difference in racial composition of youthful offenders and adult offenders cannot be explained by differences in homicide arrests: most youthful homicide offenders are white (59\%) and fewer are black (38\%). ${ }^{125}$ Most adult homicide offenders are also white (53\%) and fewer are black (44\%). ${ }^{126}$ In addition, Hispanic youth are $25 \%$ of known youthful offenders and $29 \%$ of known adult offenders. ${ }^{127}$

We also found a disparity when we focused on the race of the victim. In youthful offender cases with a single victim, two-thirds of death sentences involved a white victim, compared to $19 \%$ involving a black victim, $12 \%$ a Latinx victim and $2 \%$ an Asian victim. ${ }^{128}$ The percentages were similar for adult offenders. The overrepresentation of white victims in not as pronounced in homicide arrests. A little over half (53\%) of homicides with offenders over the age of 18 and one victim involve a white victim, 44\%

125 Supplemental Homicide Reports, supra note Error! Bookmark not defined..

${ }^{126} \mathrm{Id}$.

127 Id. The Supplemental Homicide Reports include a binary measure of ethnicity (Hispanic/not Hispanic).

128707 cases involved one victim (63\%). Ninety-five of these cases involved youthful offenders and 612 involved adult offenders. 
involve a black victim, and 2\% involve Asian victims. ${ }^{129}$

There were significant differences in the combination of offender and victim race across youthful and adult offenders. ${ }^{130}$ Of the death penalty cases with one victim since Roper, white offenders and white victims were $36 \%$ of adult offender cases, but only $24 \%$ of youthful offender cases. Black defendant and white victim cases are $19 \%$ of adult offender cases and $24 \%$ of youthful offender case: black youthful offenders are disproportionately likely to receive a death sentence for killing a white person.

Executions also overwhelmingly involved white victims in single victim cases and youthful (69\%) and adult offenders (75\%). There were significant differences in the combination of offender and victim race across youthful and adult offenders. ${ }^{131}$ Of the 364 executions with one victim since Roper, white offenders and white victims are $50 \%$ of adult offender cases, but only $31 \%$ of youthful offender cases. Black defendant and white victim cases are $19 \%$ of adult offender cases, and 31\% of youthful offender cases.

Our data also revealed significant association between offender race and whether or not the death sentence was vacated. ${ }^{132}$ Two hundred fifteen death sentences imposed since Roper have been vacated. ${ }^{133}$ In death sentences of both youthful and adult offenders, Latinx people have the lowest percentage of death sentences vacated (3\% and $10 \%$, respectively). ${ }^{134}$ In comparison, vacated youthful offender sentences are $29 \%$ white and $24 \%$ black. Similarly, vacated adult offender sentences are $20 \%$ white and $21 \%$ black.

\section{CONCLUSION}

In 1988 the Supreme Court determined that the execution of children under 16 at the time of their offense violated the Eighth Amendment's

129 Supplemental Homicide Reports, supra note Error! Bookmark not defined. There were 64,736 white offenders over the age of 18 with white victims $(n=121,659)$. There were 1,440 offenders with unknown race.

${ }^{130}$ Fisher's Exact test comparing binary race variable for both victim and offender race, $p=0.02(\mathrm{n}=641)$. There were 707 death penalty cases with one victim. We were not able to find any information about the victims in two cases. We were not able to identify the race of the victim in an additional 64 cases involving one victim (9\% of single victim cases).

131 The Fisher's Exact test is significant, $p=0.03$.

132 The Fisher's Exact test is significant, $p=0.002$.

133 Twenty-eight (13\%) vacated sentences were imposed on youthful offenders.

134 There are fewer Asian and Native American defendants, but they also have few vacated sentences. Two Asian defendants' sentences were vacated (9\%) and one of the Native American defendants' sentences was vacated (13\%). 
evolving standards of decency. ${ }^{135}$ Eighteen years later, the Court extended the categorical ban to people who were under 18 at the time of their offense. ${ }^{136}$ Juveniles, the Court explained, are categorically less culpable than older people: as "any parent knows," their brains are different from adult brains in way that make them less morally responsible for their actions. ${ }^{137}$ Simply put, youth is uniquely mitigating.

In the fifteen years since Roper, the country has witnessed dramatic developments in neuroscience, social attitudes, and most significantly, the law and attendant sentencing practices. The same considerations that motivated the Court to extend Thompson apply to people under 21: their reduced moral culpability - embodied by an increased reluctance by sentencing bodies to inflict the ultimate punishment-removes them from the category of people who can be considered the worst of the worst.

Moreover, sentencing youthful offenders to death carries the impermissible risk of arbitrariness. Black and Latinx youthful offenders are disproportionately likely to receive death sentences and to have their death sentences vacated. The risk of arbitrariness only increases when a young person of color is convicted of a crime against a white person.

The Court recognized in Roper that the 18-year cutoff was arbitrary. But it found scientific, societal and legal justifications for drawing the line there. In the intervening years, those justifications have eroded. While it is too late to save Justin Fuller from the executioner, it is time for the Court to recognize what the relevant constitutional markers make clear and extend the categorical bar to age 21.

\footnotetext{
135 Thompson __ cite.

136 Roper, _cite.

137 See Miller, 567 U.S. at 471-72.
} 